\title{
The ICT Usage in Delivering Integrated Social Welfare Services
}

\author{
Denti Kardeti $^{\mathrm{a}, \mathrm{b},{ }^{*}, \text { Budhi Gunawan }}{ }^{\mathrm{c}}$, Binahayati Rusyidi ${ }^{\mathrm{d}}$, Netty Prasetiyani ${ }^{\mathrm{e}}$ \\ ${ }^{a}$ Social Work Study Program, Post-Graduate Program, Faculty of Social and Political Sciences, Universitas Padjadjaran, Indonesia \\ ${ }^{b}$ Politeknik Kesejahteraan Sosial, Bandung, Indonesia \\ ${ }^{c}$ Departement of Anthropology, Faculty of Social and Political Sciences, Universitas Padjadjaran, Indonesia \\ ${ }^{d}$ Department of Social Welfare, Faculty of Social and Political Sciences, Universitas Padjadjaran, Indonesia \\ ${ }^{e}$ Department of Government Studies, Faculty of Social and Political Sciences, Universitas Padjadjaran, Indonesia \\ Corresponding author: *denti_kardeti@poltekesos.ac.id
}

\begin{abstract}
Fragmented social welfare services provided by the Indonesian government have resulted in unfortunate communities' difficulties, the rightful beneficiaries in accessing social aids. In response to this issue, the government established the Integrated Referrals and Services System (SLRT), covering education, health, and socio-economic services under 'one-roof' management. As discussed in the literature, either looking at the vertical or horizontal aspects of integration can be achieved. In this article, a mixedmethod approach was used to evaluate the implementation of the SLRT in Bandung District by focusing on horizontal integration, exploring the perception of beneficiaries and operators. SLRT has equipped itself with an online system named Information System of Social Welfare for the Next Generation (SIKS-NG) to improve the quality of the services further. The use of SIKS-NG can accelerate data distribution from the region to the center; data is always updated and targeted according to the service provider's needs. This study further unravels the implementation of the online system and its impacts on the SLRT. In general, it is found that the perceptions of beneficiaries and operators are in favor of SLRT. On the other hand, SIKS-NG has also been proven to improve the services delivered by operators. However, some areas of improvement were also identified for the system to be sustainable in the future.
\end{abstract}

Keywords - Social welfare services; ICT; mix-methods; Indonesia.

Manuscript received 10 Mar. 2020; revised 27 Oct. 2020; accepted 13 Dec. 2020. Date of publication 30 Jun. 2021. IJASEIT is licensed under a Creative Commons Attribution-Share Alike 4.0 International License.

\section{INTRODUCTION}

The development of information and communication technology (ICT) has brought many transformations to humankind's daily lives. It speeds up the data management and analysis used to overcome various sectors [1], [2], [3]. ICT also opens the possibility for all relevant stakeholders to be involved in the decision-making process, thus ensuring democracy [4], [5]. With the assistance of ICT, it is now also possible to expand public service coverage, such as mapping the impact on climate change to the farmers using an online database system [6]. The latest development of cutting-edge technology in ICT would also allow engineers and policymakers to process complex and challenging algorithms to deliver evidence-based policies [7]. On the other hand, the presence of ICT also lowers transaction costs in doing business compared to the conventional system [8]. This study analyses the potential benefits and obstacles in using ICT to improve social services in achieving the social welfare of the community [9], [10], [11], [12].
Social welfare is a condition of living where the community's social problems are overcome, social needs are met, and the opportunity for advancing in the social system is guaranteed [13]. Social services are essential to achieve social welfare, especially when the services are designed to overcome social problems and meet individual, family and community needs [14]. Government, non-governmental organizations, or private sectors may develop and collaborate with such services.

In addressing social welfare, Indonesia's government has been undertaking all the necessary means to meet the Millennium Development Goals (MDGs), which was discontinued in 2015. As a continuation of MDGs, the United Nations (UN) outlined the new Sustainable Development Goals (SDGs). The framework extends to 2030 as one of its primary concerns is to overcome poverty by providing comprehensive social protection [15], [16], [17].

One of the biggest challenges in delivering social protection is the fragmented service delivery system [18], [19]. The fragmented services may confuse the beneficiaries, thus resulting in problems in the delivery system. Reference [20], 
[21] argues that the fragmented services increase the difficulty level in implementing the poverty eradication agenda. In overcoming such a problem, a new paradigm emerged: integrated social protection [22]. Various research in this direction has been undertaken in Indonesia and abroad. In general, researches have been more about the formal evaluation of integrated social protection, such as those found in Sragen, Indonesia [23], Hong Kong [24], Kenya [25], Rwanda [26], and Sub-Saharan Africa in general [27]. It was suggested that integrated social protection synchronizes various sectoral developments could overcome poverty in Sragen [23].

On the other hand, previous research has reported that integrated social protection touched upon neglected problems of poverty in Hong Kong [24]. While evaluation of the formal aspect is essential, it is also essential to gain insight from the program's beneficiaries. Munday noted that both vertical and horizontal integration is of importance in delivering social services [28]. Vertical integration refers to a cross-sectoral collaboration in the government institutions, while horizontal integration refers to collaboration among experts, service providers, and beneficiaries. This research finding provides an evaluation based on beneficiaries and operators of social services.

According to the National Statistic Agency in 2016, Bandung Regency ranked third in the poverty level, with the number of poor citizens reached up to 272,560 people. To address this issue, Bandung Regency's government had allocated 497.4 billion Rupiahs for social services to establish the 'Integrated Referrals and Services System' (Sistem Layanan dan Rujukan Terpadu or SLRT) in 2016. The initiative was considered one of the best practices of integrated social services by the Ministry of Social Affairs. For this reason, the object of evaluation in the current study is the integrated referrals and services system (SLRT - Sistem Layanan dan Rujukan Terpadu), which is established in the regency (Kabupaten) administrative level. This research focuses on the implementation of SLRT in Bandung Regency, Indonesia. SLRT is also equipped with the sub-hierarchy center, namely the Social Welfare Centre (Puskesos) located in villages.

The operationalization of SLRT has relied on ICT to some extent. In the provision of computers and connecting systems in Puskesos (villages) with the primary system of SLRT (district). This research has two main objectives. First, to gather an assessment of SLRT based on beneficiaries' and operators' perspective. This assessment is about 'horizontal integration' and shall complement research focusing upon 'vertical integration' [28]. Second, this research is also evaluating the usage of ICT in delivering integrated social protection. This research argues that ICT usage may provide at least three advantages: multiplication of benefits received by people, extensification of service coverage, and reducing data duplication. With ICT, it is possible to integrate fragmented social services further and add multiple poverty indicators of beneficiaries [17], [29]. Computer and cloud storage usage also enables further widening the coverage of intended beneficiaries as geographical constraints and distance are becoming less relevant [30], [31]. Finally, unpackaged and massive data management are prone to human error. ICT would reduce the error, such as a common error of duplication data of low-income families [32].

\section{MAterials AND MethoD}

We analyzed the quantitative and qualitative data to gain more insight into beneficiaries' and operators' perspectives and evaluate the implementation of SLRT. A mixed-method with embedded concurrent strategy was selected. By mixing both data, we gain in breadth and depth of understanding and corroboration. Despite time-consuming and taking many resources, this approach allows us to identify aspects of the implementation of SLRT more accurately by using different methods and techniques.

The qualitative method was used to gather in-depth information on the implementation of integrated social services through SLRT. We conducted a series of in-depth interviews with experts and stakeholders to gather information about the history of the SLRT, the obstacles and benefits in using ICT to support SLRT, specific role played in the organization, and potential problems they experienced in their specific setting. Information was gathered from local public figures, Puskesos manager, Puskesos facilitator, Puskesos administrative staff, social care unit staff, SLRT manager, SLRT facilitator, the front, and back-office staff of SLRT, as well as beneficiaries of the integrated social services.

Additionally, a quantitative method was chosen to measure the success of SLRT through either operators' or beneficiaries' perspectives. The method was also used to explore factors affecting the success of SLRT. Many questionnaires are distributed to the sample of a population of 280 Puskesos located in 280 villages. Using Solving Equation:

$$
n=\frac{N(1)}{1+N(d)^{2}}
$$

$\mathrm{n}=$ sample size, $\mathrm{N}=$ population, $\mathrm{d}=$ margin of error $(10 \%)$

At least 74 Puskesos need to be studied by using the questionnaire. Perceptions were measured by Likert-scale ranging from Strongly Agree (SA), Agree (A), Moderately Agree (MA), Disagree (DA), and Strongly Disagree (SD). The selection of beneficiaries in each Puskesos was conducted randomly. We had been able to interview as many as 284 families across 74 Puskesos. The age of respondents was mostly between 20-45 years. Most of them were only finished elementary education and worked as daily paid laborers. These families all live on their own houses. Each house host between 1-14 family members from 1 to 2 households.

On the other hand, Puskesos' staffs that were selected as samples were 370 across 74 Puskesos. Most of the respondents were women (84\%), and most respondents' age was ranging between 36-44 years old. The validity of the test is measured by Alpha Cronbach's equation $(=0.856$; which means the questionnaire is reliable for most parts of it).

\section{RESULTS AND DISCUSSION}

The integrated social services in Bandung District comprises SLRT, a center located at the district, and Puskesos, sub-centers distributed in different villages. Nevertheless, each of the sub-center (and center) handles various social services in a one-roof system. The government built each 
centre in strategic locations so that they are accessible to the people.

The cycle of the system would involve the following sequences: 1) Beneficiaries visits Puskesos to get a referral in related to the social problems they are experiencing; 2) the back office of Puskesos determines the relevant institution in which the problems of the beneficiaries may be assisted. The back office is part of the organization to support the system without facing beneficiaries. One of the back-office functions includes dealing with technology system (IT services). This current study indicates that the back office would also consist of the Office of Demography, Education Department, and the Health Department. Common problems reported to them by beneficiaries were about Social Health Insurance (BPJS) and Education Financial Assistance (KIP); 3) the staff in the back office then input the data through an online application, which also can be assessed by the SLRT in the district. All the data gathered in SLRT constituted what is called as Integrated Database (BDT), which is updated monthly. Through the connected system, each manager in different tier was able to monitor the progress of reports posted by beneficiaries.

\section{A. The Profile of SLRT}

The Integrated Referrals and Services System (SLRT Sistem Layanan dan Rujukan Terpadu) is a combined system that identifies needy people's needs and connects them to social protection programs and poverty alleviation implemented by different administrative tiers of government (see Figure 1). Further, SLRT also identifies reports made by beneficiaries, follows up reports by making referrals, and monitors reports' handling. This system is mainly designed to optimize social welfare sources located in the smallest administrative area unit.

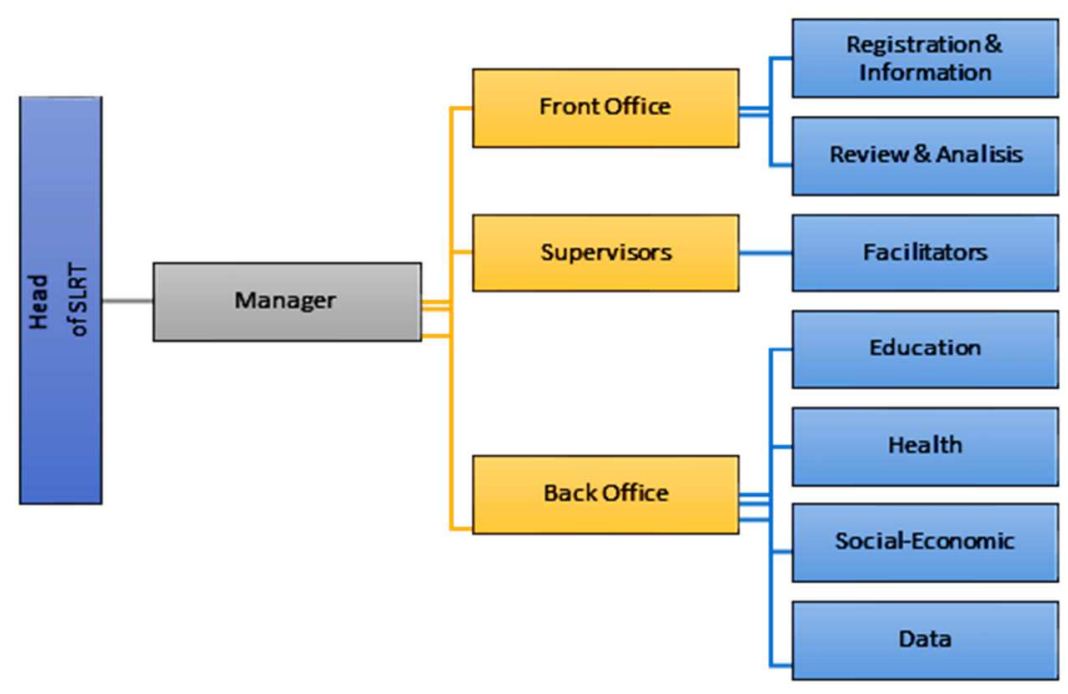

Fig. 1 The organizational structure of SLRT

Sabilulungan SLRT is a part of the program implemented by the Social Department of the District of Bandung. Stipulated by Head of the District of Bandung 66/2016, local governments' fragmented social services inspired the program. SLRT at the district level is supported by the Social Welfare Centre (Puskesos) located in villages. Puskesos focuses on education, health, population, and other basic social services needed by the people. SLRT is integrated with Puskesos, which made them both a Single Window Services aimed to provide fast, easy, and cheap services for the unfortunate residents.

The organizational structure of SLRT consists of the Head of SLRT (Head of Social Department of Bandung District) and two supporting offices: front office and back office. The front office consists of Information and Registration Section as well as Analysis and Review Section. In comparison, the back office consists of four sections: education, health, social economy, and data management. These two offices are managed by a manager, who is also assisted by supervisors and facilitators.

SLRT covers all 280 villages located in Bandung District. Each village has 1 facilitator and 1 Puskesos. The main target of SLRT is the poor and near-poor households. According to the Integrated Social Welfare Database, poor are people below the national poverty line, while near-poor in the bottom $40 \%$ of income. These categories also cover people with disability, abandoned children/women, elderly and remote indigenous community. Fig. 2 below depicts the procedure of SLRT in handling reports given by beneficiaries.

There are three ways for beneficiaries to access SLRT services: 1) by coming directly to SLRT in the District of Bandung; 2) by coming to nearby Puskesos; 3) beneficiaries are visited by local facilitators. In a hierarchical style, if the needs of beneficiaries could not be met by programs available in the villages, the reports are then forwarded to the subdistrict supervisor to be reviewed. These reports then are forwarded to SLRT in Bandung District to be addressed by relevant departments in the district.

\section{B. ICT in the Undertaken of SLRT}

Referring to Fig. 2 above, the data management and reporting system used by SLRT is supported by ICT. The system consists of one administrator, one manager, 31 supervisors (corresponds to the total number of sub-districts) and 280 facilitators (corresponds to the total number of villages). All these staffs are equipped with IT devices and may use two different systems: Android-based application or web-based application. 


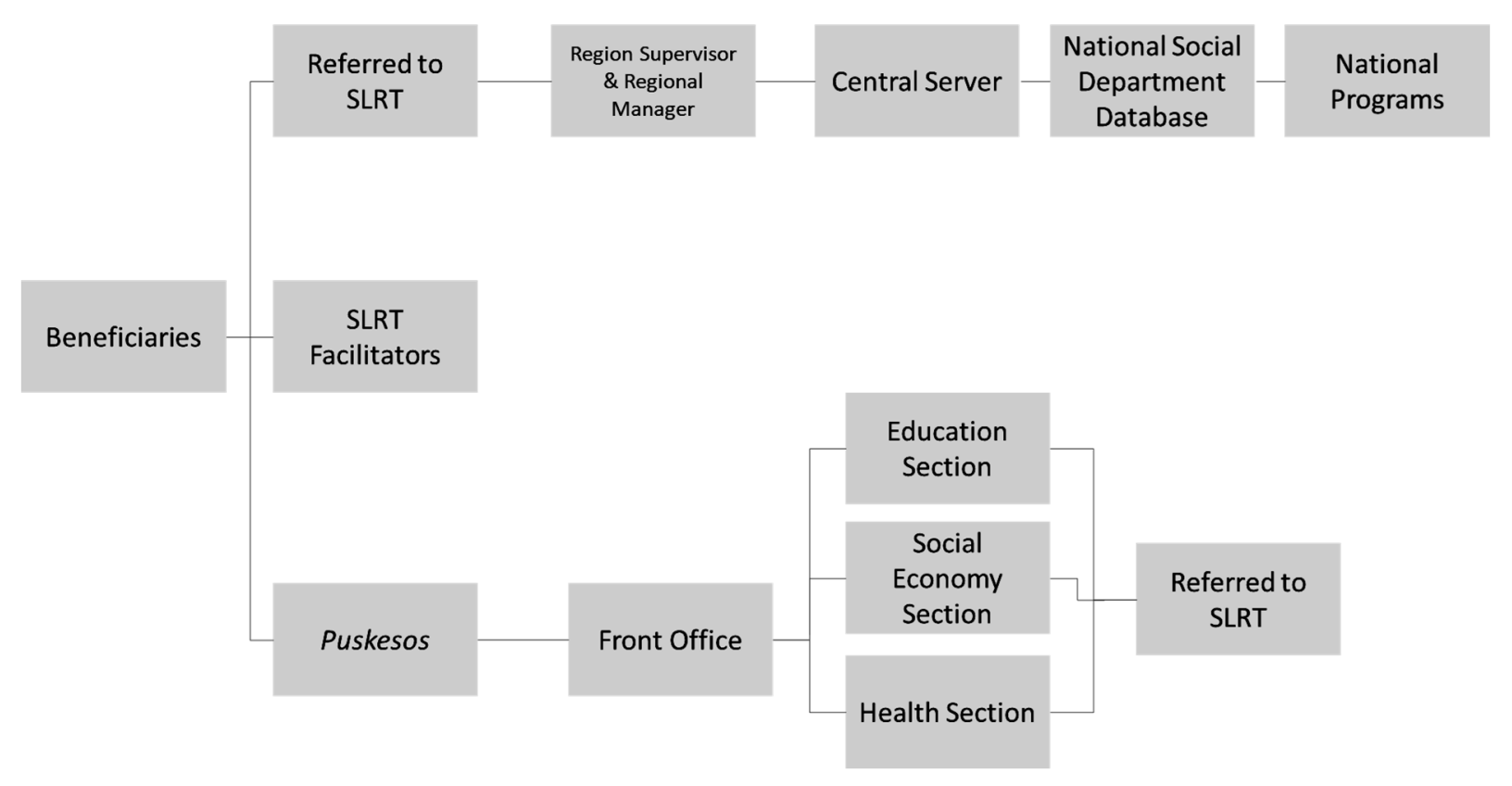

Fig. 2 SLRT flow of work

The administrator serves as the center of communication between regional and central staffs. The administrator's tasks cover: 1) creating username and password for each staff; 2) adding regional programs; 3 ) reporting problems in related to application usage; 40 coordinating with the National Secretariat. The administrator is using the web-based SLRT application.

The manager is an organizer who holds an important role in making all referrals to the relevant program coordinator. The manager employs a web-based SLRT application, and it covers all area in Bandung District. On the other hand, a supervisor is SLRT organizers at the sub-district level. The supervisor's role is to review reports made by beneficiaries that could not be handled at the village level. The supervisor may also forward the reports to the manager in the district. The supervisor's additional tasks are disseminating the SLRT program in their sub-districts and coordinating with facilitators to disseminate the program in villages. The supervisor is also using web-based SLRT application with the coverage area is only in their sub-districts.

Different from another line of staffs, facilitators use Android-based application, filled with Integrated Social Welfare Database. The application is installed in a tablet to record reports made by households. Moreover, the application provides complete information on all social welfare programs available. The main task of the facilitator is to be the frontline in assisting beneficiaries. The specific tasks of facilitators include: 1) beneficiaries profile searching; 2) verification and record of residents' profile changing; 3) integrated database validation; 4) to record beneficiaries; 5) to record programs needed by beneficiaries; 6) to record complaints.

SLRT application hold by facilitators is integrated with both supervisor's and manager's application. The manager forwards data collected by facilitators to the National Data Center. Additionally, there is also a system called Information System of Social Welfare for the Next Generation (SIKS-NG) in each Puskesos. This system collects data that has been verified by facilitators. Then, data is being updated once every six months by the village's forum. As one interviewee commented:

"SLRT provides initial data as an input for the verification and validation done through SIKS-NG. SLRT also assisted Puskesos in updating profiles of poor and near-poor people on the Integrated Database." (Interview, $25^{\text {th }}$ July 2019)

The National Data Center is also equipped with a webbased dashboard displaying 1) summary of updated reports and data addition of beneficiaries; 2) a list of national and local social welfare programs; 3) gap of services between national and local government. The dashboard is particularly useful in the budgeting and plan-making process.

\section{Perception of the SLRT Implementation}

In general, the reports gained from beneficiaries were transferred to the relevant department either through social media, telephone, or off-line conversation (face to face communication). Cross-sectoral problems require cooperation among different departments. For example, beneficiaries' health deprivation due to the broken houses may require assistance from the Health Department and the Public Work Department, respectively. If the allocated government budget is insufficient, the private sector may be involved through the Corporate Social Responsibility (CSR) program. To ensure the quality of 'vertical integration' as aforementioned in section 1, we have analyzed the questionnaire results below in a highlighted style.

According to the questionnaire result, majority of the beneficiaries consider the services provided by Puskesos have been satisfactory (more than $75 \%$ answering Agree or Strongly Agree). Beneficiaries knew the location of Puskesos, and it is accessible. By knowing the location of Puskesos, beneficiaries may involve actively in reporting problems. Therefore, solutions delivered in villages are expected to be effective because they meet the targets. 
TABLE I

PERSPECTIVES OF BENEFICIARIES $(\mathrm{N}=284)$

\begin{tabular}{|c|c|c|c|}
\hline$\#$ & Question & SD-DA-LA* & A-VA* \\
\hline 1 & $\begin{array}{l}\text { Finding out the } \\
\text { location of Puskesos }\end{array}$ & $9(3.17 \%)$ & $275(96.83 \%)$ \\
\hline 2 & $\begin{array}{l}\text { Knowing the staffs of } \\
\text { Puskesos }\end{array}$ & $8(2.82 \%)$ & $276(97.18 \%)$ \\
\hline 3 & $\begin{array}{l}\text { Knowing services } \\
\text { provided by Puskesos }\end{array}$ & $16(5.64 \%)$ & $268(94.36 \%)$ \\
\hline 4 & Puskesos is accessible & $12(4.22 \%)$ & $272(95.78 \%)$ \\
\hline 5 & $\begin{array}{l}\text { Services requirement } \\
\text { (documents) are easily } \\
\text { understood }\end{array}$ & $8(2.82 \%)$ & $276(97.18 \%)$ \\
\hline 6 & $\begin{array}{l}\text { Social-economy, } \\
\text { health and education } \\
\text { services are under } \\
\text { one-roof }\end{array}$ & $26(9.15 \%)$ & $258(90.85 \%)$ \\
\hline 7 & $\begin{array}{l}\text { Services procedure is } \\
\text { considered good }\end{array}$ & $14(4.93 \%)$ & $270(95.07 \%)$ \\
\hline 8 & Timely services & $12(4.22 \%)$ & $272(95.78 \%)$ \\
\hline 9 & $\begin{array}{l}\text { No additional cost for } \\
\text { services }\end{array}$ & $2(0.7 \%)$ & $282(99.3 \%)$ \\
\hline 10 & $\begin{array}{l}\text { Staffs of Puskesos } \\
\text { have a good } \\
\text { communication skill }\end{array}$ & $4(1.41 \%)$ & $280(98.59 \%)$ \\
\hline 11 & $\begin{array}{l}\text { Puskesos staff able to } \\
\text { recap all the reports }\end{array}$ & $8(2.82 \%)$ & $276(97.18 \%)$ \\
\hline 12 & Staffs were patient & $8(2.82 \%)$ & $276(97.18 \%)$ \\
\hline 13 & $\begin{array}{l}\text { Puskesos increases the } \\
\text { quality of service and } \\
\text { make things easier }\end{array}$ & $6(2.11 \%)$ & $278((7.89 \%)$ \\
\hline 14 & $\begin{array}{l}\text { Facilities in Puskesos } \\
\text { are complete }\end{array}$ & $84(29.6 \%)$ & $200(70.4 \%)$ \\
\hline
\end{tabular}

* $\mathrm{SD}=$ Strongly Disagree; $\mathrm{D}=$ Disagree; $\mathrm{MA}=$ Moderately Agree; $\mathrm{A}=$ Agree; $\mathrm{SA}=$ Strongly Agree

Puskesos' staffs become the frontier in mitigating social problems reported by beneficiaries. According to the questionnaire result, staff were considered patient and possessed the necessary skill to verify and validate beneficiaries' data. Private data is a vital aspect. These classified data should be maintained so the data shall not be used for other purposes than they should be. As one interviewee explained:

\begin{abstract}
"Beneficiaries generally need information on each program offered by SLRT. For example, once I received complaints on the education financial assistance from a beneficiary. He has three kids; first, nearly graduated from Junior High School; second, graduated from Senior High School; third, currently is on the $6^{\text {th }}$ grade. The third son never received financial assistance. The beneficiary asked whether it is possible or not to transfer the assistance from the second child to the third child. We are now coordinating to resolve this issue." Interview, $15^{\text {th }}$ July 2019 ()
\end{abstract}

Beneficiaries knew services provided by Puskesos. It has resulted in the integration of information and services and mutual relation between beneficiaries and Puskesos' staff. Beneficiaries were able to identify referral needed because they have understood the nearest system that may assist them. Active participation from beneficiaries has made member registration easier, thus resulting in more effective poverty alleviation.

On the aspect of the requirement to access the service, beneficiaries considered that all administrative documents were easily obtained and prepared, such as ID, birth certificate, and others. These are the basic documents that may need to be complemented by additional requirements. Majority of beneficiaries also considered the integrated social service had been implemented under the one-roof mechanism.

Nevertheless, the questionnaire result showed a relatively high rate of dissatisfaction in terms of the facility provided in Puskesos, such as chairs, information board, and complaint boxes. This aspect needs to be improved for beneficiaries to be able to receive optimum service. We also gather information from the perspective of Puskesos' staffs, as outlined below.

TABLE II

Perspectives of PUSKesos' Staffs $(\mathrm{N}=370)$

\begin{tabular}{lll}
\hline Question & SD-D-MA* & A-SA* \\
\hline $\begin{array}{l}\text { Services provided have } \\
\text { met the goal set by the }\end{array}$ & $54(14.6 \%)$ & $316(85.4 \%)$ \\
institution & \\
*SD $=$ Strongly Disagree; D = Disagree; MA = Moderately Agree; A = Agree; \\
SA = Strongly Agree
\end{tabular}

Table 2 above shows that the majority of Puskesos' staff considered that services had met the standard set up by the institution. It has been recorded a gradual increase in the budget allocated by the District Government to develop the facilities of SLRT in the year 2019 and 2020 was 9.4 million. Nevertheless, $14.6 \%$ of staff were Moderately Agree on the matter. Staffs faced obstacles inclusive of an error in the system due to the high number of statistics that need to be recorded. Some villages are also located in remote areas with limited communication signals, thus impeding online systems' implementation. All the obstacles faced contributed to the delay in the services.

Additional problems also came from beneficiaries that sometimes they did not follow the procedure in accessing the social service. For example, some beneficiaries opt to come to the district's SLRT centre directly and did not come to Puskesos in their villages first. This action disrupted the system since it was impossible for the SLRT's staffs to reject beneficiaries, and on the other hand, the role of Puskesos as sub-branches of SLRT in terms of data collecting was undermined.

\section{Evaluation of the ICT Support on SLRT}

To evaluate the benefits of using ICT in SLRT, we also conducted an in-depth interview with 13 respondents namely the manager, the staff at the National Secretariat, three supervisors, three facilitators and five Puskesos employees. In general, a common view amongst interviewees was that the system had been used due to several benefits. First, the system has been integrated with various social welfare programs, thus enable staffs to handle reports efficiently. Second, it is the only system that can access Social Welfare Integrated Database. Third, the security of the system is assured since each staff is being given a unique username. Therefore, data mishandling and breaching can be avoided. Fourth, the system is not installing any data to gadgets, but the software allows staffs' gadget to pull up data from the database. Therefore, there is no requirement for installing anti-virus in staffs' gadget. Regular backups of data are also done to prevent data loss due to corrupted files. As one interviewee said: 
"The National Data Center possess an integrated database. The database has been compiled by facilitators using their tablets. The data originally came from census held by the National Statistic Agency in 2016. In 2018, SIKS-NG was established, which is the initial step towards establishing the Integrated Database. Currently, the integrated database owned by the National Data Center is distributed through SIKS-NG to all relevant villages." (Interview, $25^{\text {th }}$ July 2019)

According to interview transcripts, the employee working with the system have an appropriate qualification. At the National Secretariat, there are five workers with the university level of education. They have a responsibility as 1) one Android-based application developer; 2) one web-based application developer; 3) one database specialist to maintain servers and regularly update server; 4) one helpdesk whose duty is to respond to any problems faced in the usage of the application and to report to developers and database specialists; 5) one project manager whose tasks is to coordinate, monitor and arrange jobs distribution across staffs.

At the district level, staff working on the application do not have an IT background. As mentioned before, the number of staffs are 280 facilitators, 31 supervisors and 1 manager. The manager has a post-graduate education background. While supervisors have a bachelor diploma, facilitators mostly only hold a senior high school diploma. Following this, the National Secretariat regularly conduct training for local staff to overcome the knowledge gap by upgrading the skill and understanding of supervisors and facilitators. Thus, they can deliver excellent services to beneficiaries. The local government provides the budget to hold training at least twice a year.

Puskesos and facilitators are on the front line in recording reports and complain from beneficiaries (Figure 3). Their main activities include validating and updating data. Puskesos is equipped with a personal computer to access the web-based application, while facilitators are given tablets to access the Android-based application. In this system, both supervisors and manager are responsible for reviewing and forwarding data recapitulation made by facilitators and Puskesos' staff. Also, both the supervisor and the manager are obligated to address any problems that can be addressed at the local level based on the report from beneficiaries.

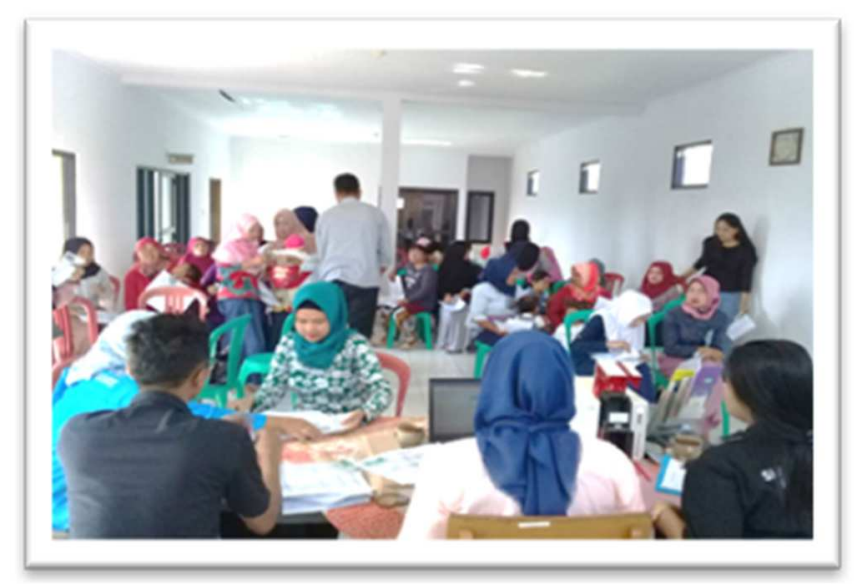

Fig. 3 Pusksesos Gambung Walagri Village of Mekarsari

The usage of ICT has been improving the implementation of SLRT. It helps the government integrate various social welfare programs in a single application and database to be assessed by beneficiaries and operators. On the other hand, it also extends the coverage of poor people by providing an online system. Additionally, regular updates on the system also assure the absence of data duplication among beneficiaries.

A variety of perspectives were expressed when the interviewees shared about the obstacles. First, in assessing the application, some remote areas, such as villages in the distance more than $40 \mathrm{~km}$ from Bandung District's capital, it has been reported that internet signal has been problematic. These areas are typically labelled as Zone 3 and cover 12 subdistricts (out of 31 districts). This study found that residents in the remote area face limited availability and accessibility to the internet signal. Although technology has the potential to support isolated beneficiaries [33], the availability of the internet becomes the priority in developing welfare community. Second, staff's ability and capability, particularly Puskesos' employees and facilitators to use the application, have been somewhat imperfect due to the staff's educational background who are not related to their current work. Social workers' use of technology has created new ways to interact and communicate with clients by using various forms of technology to access, gather, and otherwise manage information about their clients. The penetration of technology in their job creates new challenges for them, particularly when incorporating technology into social work. Majority of social workers use computers to gather clinical information. Third, the limited availability of personal computers or laptops to access SIKS-NG application in terms of capacity and specification in several villages (Figure 4). These types of equipment are not available due to the limited budget. It sometimes resulted in the delay of the service due to system error. Lastly, training conducted by the National Secretariat's staffs has been considered lacking.

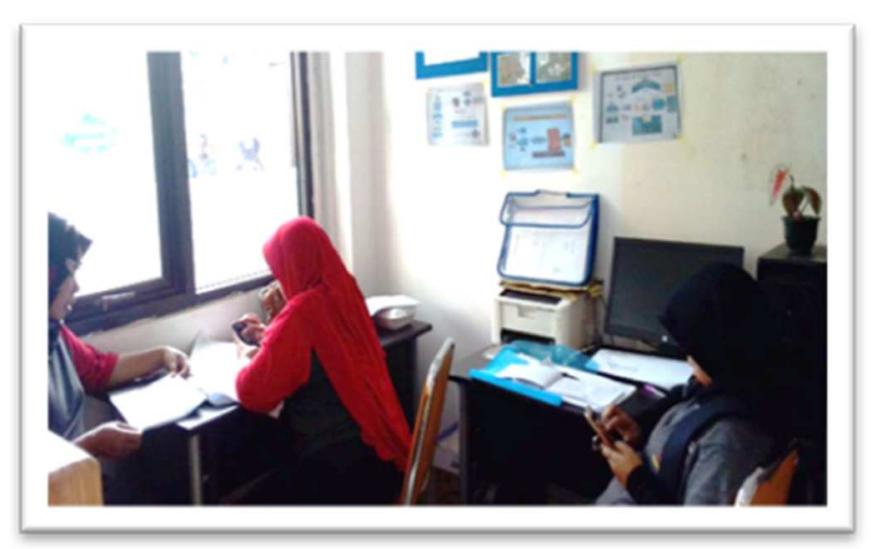

Fig. 4 ICT room in Puskesos Sekarwangi Sub-District Soreang

\section{E. Further Improvements}

In general, the usage of SIKS-NG in delivering integrated social services SLRT has improved the quality of services. Previously, before the establishment of the system, staff were using paper-based. Moreover, filling forms have been taking so much time as compared by using application currently. Another benefit of using the application is the possibility of covering remote areas staff can use some application features without the internet. 
To further increase the underprivileged people's benefits, several improvements are needed to optimize the program. The integrated social services implemented through SLRT was initially aimed to bring all social problems reported by beneficiaries under one roof. The establishment of SIKS-NG has been assisting this development. Four areas of development are needed to be addressed to bring SLRT to the next level (Fig 4.).

First, regular training is needed to be improved to develop the competency of social workers. Various training needs to be added, so does the frequency. Second, software and hardware upgrading is utmost importance in avoiding further delay in services due to glitch and error in the system. Electronic data management (EDM) services, electronic medical records (EMR), and electronic health records (HER) are good examples of software application platforms that social workers might use to managing client's personal data. Third, now, social welfare services provide are limited to social-economic, education and health. Additional services may be added on the characteristics of local people where Puskesos is located. Fourth, given the possible upgrading of software, hardware, and additional staff, extending the services' coverage by adding more villages or even replicating SLRT in other districts is possible. Taken together, the nexus between social work practice and ICT are the resources of people and technology. The human capacity that resilient and resistant could optimise the usage of ICT to achieve social welfare.

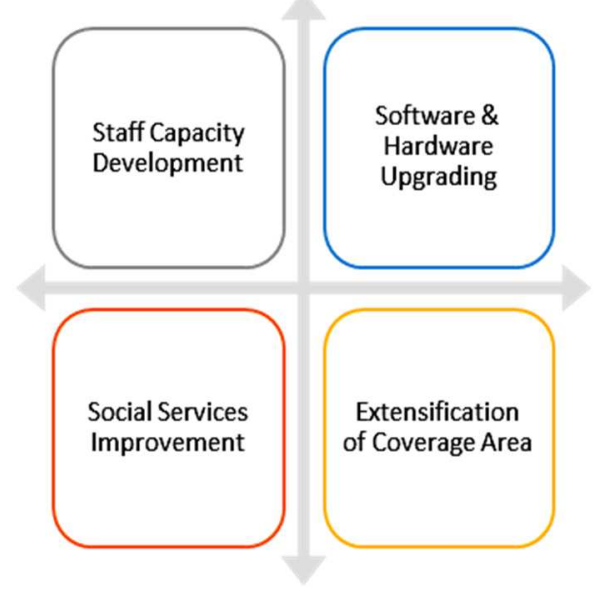

Fig. 5 Area of improvement for the application based SLRT

\section{CONCLUSION}

The integrated social services SLRT was founded to solve the government's fragmented social services. As mentioned before, to measure the integration among different parties and services, both vertical and horizontal integration are of importance. The study's result regarding horizontal integration shows that most of the beneficiaries found that SLRT has been assisting them well in dealing with their social problems. The social department considers that most objectives of their institution have been achieved via the implementation of SLRT.

On the other hand, the use of ICT has also improved the quality of SLRT. Not only it assists the integration of many social programs delivered, but also it has been able to widen the area of beneficiaries covered by the system. Specifically, it also helps in decreasing the potential of data duplication and data breach. Nevertheless, further improvement in the aspect of staff capacity, hardware upgrading, social services providers and coverage area may be beneficial for the system's sustainability and specifically for the beneficiaries.

\section{ACKNOWLEDGMENT}

We would like to thank Politeknik Kesejahteraan Sosial (Poltekesos) Bandung for the financial assistance given to undertake this research.

\section{REFERENCES}

[1] I. Røpke and T. H. Christensen, "Transitions in the wrong direction? Digital technologies and daily life," in Sustainable Practices: Routledge, 2013, pp. 65-84.

[2] Á. C. Pinto-Bruno, J. A. García-Casal, E. Csipke, C. Jenaro-Río, M. J. A. Franco-Martín, and M. Health, "ICT-based applications to improve social health and social participation in older adults with dementia. A systematic literature review," vol. 21, no. 1, pp. 58-65, 2017.

[3] H. Yeh, "The effects of successful ICT-based smart city services: From citizens' perspectives," J Government Information Quarterly, vol. 34, no. 3, pp. 556-565, 2017.

[4] S. H. Doong and S.-C. Ho, "The impact of ICT development on the global digital divide," Electronic Commerce Research Applications, vol. 11 , no. 5 , pp. 518-533, 2012.

[5] C. J. Lee, "Effects of sport mega-events on city brand awareness and image: using the 2009 world games in Kaohsiung as an example," (in English), Quality \& Quantity, vol. 48, no. 3, pp. 1243-1256, May 2014.

[6] P. K. Gangopadhyay, A. Khatri-Chhetri, P. B. Shirsath, and P. K. J. C. c. Aggarwal, "Spatial targeting of ICT-based weather and agroadvisory services for climate risk management in agriculture," vol. 154, no. 1-2, pp. 241-256, 2019.

[7] D. Añón Higón, R. Gholami, and F. Shirazi, "ICT and environmental sustainability: A global perspective," Telematics and Informatics, vol. 34, no. 4, pp. 85-95, 2017/07/01/2017.

[8] L. W. W. Mihardjo, Sasmoko, F. Alamsjah, E. J. I. J. o. Economics, and B. Research, "Digital transformation: a transformational performance-based conceptual model through co-creation strategy and business model innovation in the Industry 4.0 in Indonesia," vol. 18, no. 3, pp. 369-386, 2019.

[9] D. Nevado-Peña, V.-R. López-Ruiz, and J.-L. Alfaro-Navarro, "Improving quality of life perception with ICT use and technological capacity in Europe," Technological Forecasting Social Change, vol. 148, p. 119734, 2019.

[10] T. D. Lee, H. Park, and J. Lee, "Collaborative accountability for sustainable public health: A Korean perspective on the effective use of ICT-based health risk communication," Government information quarterly, vol. 36, no. 2, pp. 226-236, 2019.

[11] C. Chan, "ICT-supported social work interventions with youth: A critical review," Journal of Social Work Education, vol. 18, no. 4, pp. 468-488, 2018.

[12] T. Olsson, U. Samuelsson, and D. Viscovi, "At risk of exclusion? Degrees of ICT access and literacy among senior citizens," $J$ Information, Communication Society, vol. 22, no. 1, pp. 55-72, 2019.

[13] H. Soelaiman, Kesejahteraan Sosial (Konsep dan Praktik). Bandung: STKS Press, 2017.

[14] A. I. Rukminto, "Ilmu Kesejahteraan Sosial dan Pekerjaan Sosial," ed: Jakarta: FISIP UI Press, 2005.

[15] W. Wahyuningsih, "Millenium Develompent Goals (Mdgs) Dan Sustainable Development Goals (SDGs) Dalam Kesejahteraan Sosial," Jurnal Bisnis dan Manajemen, vol. 11, no. 3, pp. 390-399, 2018.

[16] V. Varghese and A. Jana, "Interrelationships between ICT, social disadvantage, and activity participation behaviour: A case of Mumbai, India," Transportation Research Part A: Policy Practice, vol. 125, pp. 248-267, 2019.

[17] K. Mavrou, M. Meletiou-Mavrotheris, A. Kärki, M. Sallinen, E.-J. J. T. Hoogerwerf, and Disability, "Opportunities and challenges related to ICT and ICT-AT use by people with disabilities: An explorative study into factors that impact on the digital divide," vol. 29, no. 1-2, pp. $63-75,2017$. 
[18] A. C. Bunger, "Defining service coordination: A social work perspective," Journal of social service research, vol. 36, no. 5, pp. 385-401, 2010.

[19] W. Berenschot, "Informal democratisation: brokers, access to public services and democratic accountability in Indonesia and India," $J$ Democratization, vol. 26, no. 2, pp. 208-224, 2019.

[20] F. Haile and M. Niño-Zarazúa, "Does Social Spending Improve Welfare in Low-income and Middle-income Countries?" Journal of International Development, vol. 30, no. 3, pp. 367-398, 2018.

[21] M. Sumarto, "Welfare regime change in developing countries: evidence from Indonesia," J Social Policy Administration, vol. 51, no. 6, pp. 940-959, 2017.

[22] N. C. Ware, K. Hopper, T. Tugenberg, B. Dickey, and D. Fisher, "Connectedness and citizenship: Redefining social integration," Psychiatric services, vol. 58, no. 4, pp. 469-474, 2007

[23] M. Muhtar and I. Huruswati, "Pelayanan Satu Pintu Penanggulangan Kemiskinan Di Sragen," Sosio Konsepsia, vol. 5, no. 1, pp. 277-291, 2015.

[24] D. o. S. W. a. S. Administration., "Report on the Review of Family Services "Meeting the Challenge: Strengthening Families"," The University of Hong Kong Hong Kong 2001.

[25] N. Jensen, M. Ikegami, and A. Mude, "Integrating social protection strategies for improved impact: A comparative evaluation of cash transfers and index insurance in Kenya," The Geneva Papers on Risk Insurance-Issues Practice, vol. 42, no. 4, pp. 675-707, 2017.

[26] T. S. Betancourt et al., "Integrating social protection and early childhood development: open trial of a family home-visiting intervention, Sugira Muryango," J Early Child Development Care, 2018 .

[27] S. A. Asongu and S. Le Roux, "Enhancing ICT for inclusive human development in Sub-Saharan Africa," J Technological Forecasting Social Change, vol. 118, pp. 44-54, 2017.

[28] B. Munday, "European social services: A map of characteristics and trends," J Strasbourg, Council of Europe, vol. 3, no. 1, 2003.

[29] A. Hill and I. Shaw, Social work, and ICT. Sage Publications, 2011.

[30] E. Harlow and S. A. Webb, Information, and communication technologies in the welfare services. Jessica Kingsley Publishers, 2003.

[31] F. G. Reamer, "Social work education in a digital world: Technology standards for education and practice," Journal of Social Work Education, vol. 55, no. 3, pp. 420-432, 2019.

[32] T. E. Kidd and I. L. Chen, Social information technology: Connecting society and cultural issues. Information Science Reference/IGI Global, 2008.

[33] R. Csiernik, P. Furze, L. Dromgole, and G. M. J. J. o. E.-B. S. W. Rishchynski, "Information technology and social work-The dark side or light side?" vol. 3, no. 3-4, pp. 9-25, 2006. 